\title{
Frontier Forms of Iowa's County Seats
}

\author{
TOM SCHMIEDELER
}

IN THE SUMMER OF 1879 five prominent business associates from Dubuque formed the Allison Town Company to plat what was to become Iowa's last county seat. Town company members had planned Allison as early as 1875 in conjunction with the projected line of the Iowa and Pacific Railroad across the northern half of the state, but because of financial difficulties the railroad completed only grading of the line. In 1879 the Dubuque and Dakota Railroad, known locally as the "Damned Doubtful" because of the reputation of its predecessor, completed the line through Butler County, and Allison finally lost its status as a "paper town."

The process of establishing Allison was similar to that of many other "railroad towns" in the Midwest, where individuals, town companies, and railroads and their affiliated companies established towns quick on the heels of railroad construction across the region. A close inspection of Allison's original plat, though, reveals as much about the varying role of county seats in Iowa's settlement history as it does about railroad townsite strategies in the Midwest. The plat shows narrow lots designed for businesses extending from the railroad tracks in a classic "T-town" configuration, a common railroad town design (fig. 1). The most imposing feature of the plat, however, is a ten-acre square located at the opposite end of the intended business district from the tracks.

I would like to thank three anonymous reviewers for their critical comments, which greatly improved the quality of this article. I would also like to thank James R. Shortridge for his helpful editorial suggestions.

1. Ray L. Bryant, A Preliminary Guide to Iowa Railroads, 1850-1972 (Iowa City, 1984).

THE ANNALS OF IOWA 57 (Winter 1998). CThe State Historical Society of Iowa, 1998: 
2 THE ANNALS OF IOWA

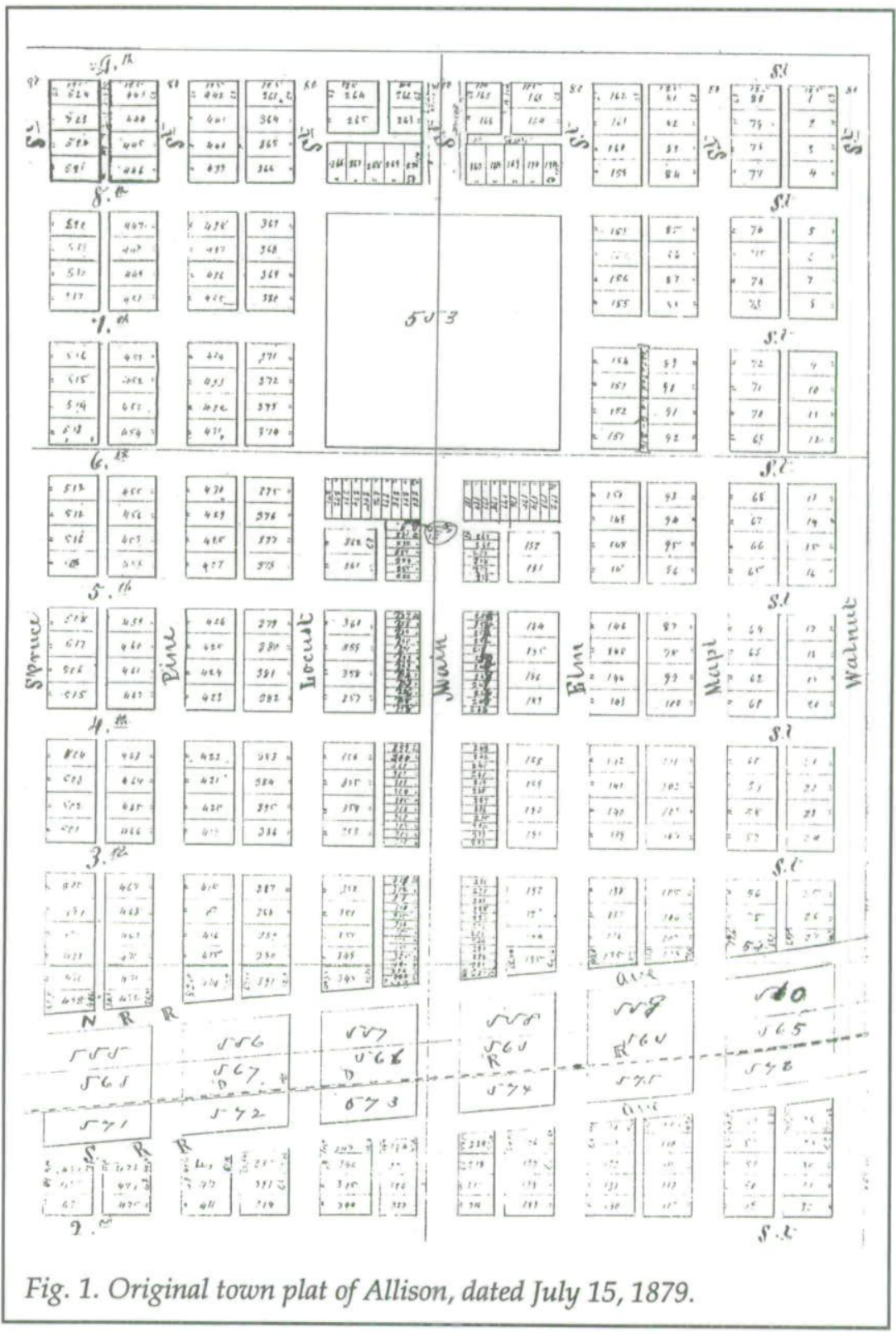

By 1879, Iowa's town planners were very familiar with the idea of town squares. They had incorporated such squares into their town designs since counties began to be formed in the 


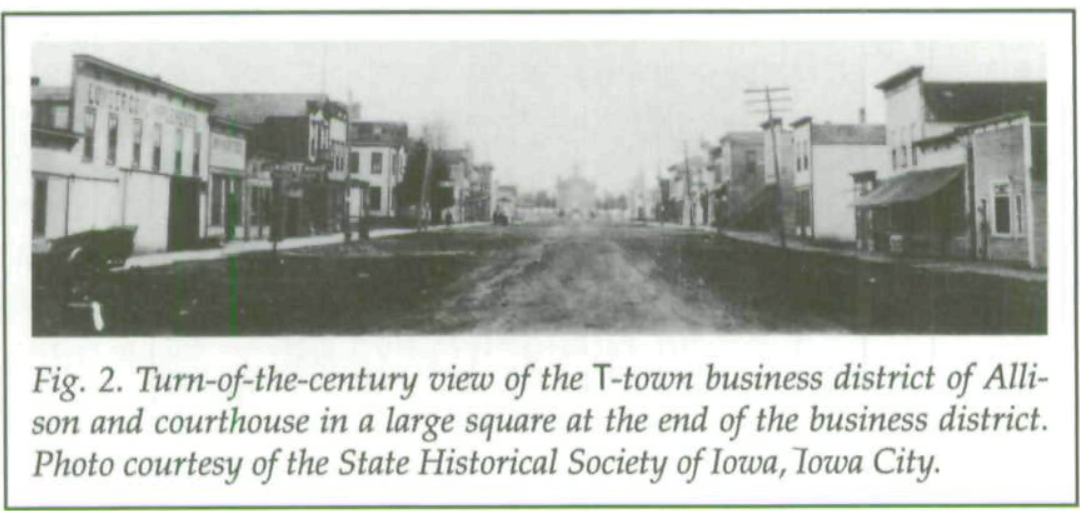

$1830 \mathrm{~s}$ and $1840 \mathrm{~s}$. In fact, the central courthouse square plan had acquired a distinctive regional geography in Iowa during the first half of the state's settlement period. Allison did not develop into a central courthouse-square town, but its plat and subsequent development suggest that the idea of public space remained a powerful component of urban planning to the end of the era of county seat formation in the state, even after railroads had come to dominate town-founding processes, introducing alternative, corporate designs to the urban landscape. Allison's form, therefore, represented competing ideas, or ideologies, in the minds of its planners about what a town should be. The result of those competing ideologies was a compromise of urban forms, with the principal elements of each form - courthouse square and tracks and depot-anchoring the ends of the linear business district that linked representative design elements of earlier and later periods of town planning in Iowa (fig. 2).

Allison's frontier development shows how an analysis of the physical forms of towns, consisting of "the detailed interplay of land subdivision, buildings and their combined patterns of use," can shed new light on the role of towns in frontier settlement. ${ }^{2}$ The initial land subdivision of any town, as

2. Michael P. Conzen, "Town-plan Analysis in an American Setting: Cadastral Processes in Boston and Omaha, 1630-1930," in The Built Form of Western Cities: Essays for M. R. G. Conzen on the Occasion of His Eightieth Birthday, ed. Terry R. Slater (Leicester, 1990), 144. 
represented by its original town plat, is its most durable form component. After the initial platting, street and land parcel patterns seldom change even though the original buildings that stood on them may be long gone. ${ }^{3}$ The original plan can thus serve as a blueprint for evaluating subsequent changes in land-use patterns and buildings of an individual town. An analysis of town forms from the perspective of frontier urbanization processes has an additional application when one considers original town plans in combination with the initial location of commercial and public buildings. Together the two elements provide the basis for classifying frontier urban forms because they reflect not only the various ideologies of their planners but also the degree of their power to control frontier urban development. Thus, patterns of frontier forms can be used to assess how ideas governing town-founding processes changed with the progression of frontier settlement.

Despite these potential applications, scholars have largely overlooked aspects of urban form in their research on frontier urbanization. Instead, they have emphasized factors influencing the growth of frontier places, particularly those factors associated with external economic forces active in the earliest stages of regional development. ${ }^{4}$ Theories of urban growth structured around multistage models, for example, have stressed the im-

3. James E. Vance Jr., This Scene of Man: The Role and Structure of the City in the Geography of Western Civilization (New York, 1977), 4.

4. John Borchert, "American Metropolitan Evolution," Geographical Review 57 (1967), 301-23; Michael P. Conzen, "A Transport Interpretation of the Growth of Urban Regions: An American Example," Journal of Historical Geography 1 (1975), 361-82; F. A. Dahms, "The Evolution of Settlement Systems: A Canadian Example, 1851-1970," Journal of Urban History 7 (1981), 169-204; Timothy R. Mahoney, "Urban History in a Regional Context: River Towns on the Upper Mississippi, 1840-1860," Journal of American History 72 (1985), 318-39; Edward K. Muller, "Regional Urbanization and the Selective Growth of Towns in North American Regions," Journal of Historical Geography 3 (1977), 21-39; Douglass C. North, "Location Theory and Regional Economic Growth," Journal of Political Economy 63 (1955), 243-58; Allan Pred, Urban Growth and City Systems in the United States, 1840-1860 (Cambridge, MA, 1980); Anne Mosher Sheridan, "The Development of Nucleated Settlement Systems: The Case of the Upper Mississippi Valley, 1800-1860" (M.S. thesis, Pennsylvania State University, 1983); James E. Vance Jr., The Merchant's World: The Geography of Wholesaling (Englewood Cliffs, NJ, 1970); Charles F. J. Whebell, "Corridors: A Theory of Urban Systems," Annals of the Association of American Geographers 59 (1969), 1-26. 
portance of evolving transportation systems, interregional trade and trading entrepôts, and market specialization. Of those researchers who have considered aspects of urban forms, few have emphasized their diverse spatial patterns. ${ }^{5}$

Iowa is a good case study to test assumptions about patterns of frontier forms and their representative ideologies because people who settled Iowa came from a variety of regional subcultures, each of which had developed its own urban planning traditions. Moreover, the Iowa frontier was settled when "major population growth and successful regional development generated conditions for urban fluorescence on a scale unknown in colonial times, and this encouraged a morphological divergence from past traditions. ${ }^{16}$ County seats are especially suggestive because their forms embodied attitudes of culture groups toward the role of government in the frontier settlement process. As Carl Sauer once observed, "No groups coming from different civilizations and animated by different social ideals have reacted to frontier life in identical fashion. ... there was no single type of frontier, nor was there a uniform series of stages. The nature of the cultural succession that was initiated in any frontier area was determined by the physical character of the country, by the civilization that was brought in, and by the moment of history that was involved."

5. An exception is Edward T. Price, "The Central Courthouse Square in the American County Seat," Geographical Review 58 (1968), 29-60. See also Michael Conzen, "The Morphology of Nineteenth-Century Cities in the United States," in Urbanization in the Americas: The Background in Comparative Perspective, ed. W. Borah, J. Hardoy, and G. Styelter (Ottawa, 1980); Richard V. Francaviglia, Main Street Revisited: Time, Space, and Image Building in SmallTown America (Iowa City, 1996); John C. Hudson, Plains Country Towns (Minneapolis, 1985); Richard R. Pillsbury, "The Urban Street Pattern as a Culture Indicator: Pennsylvania, 1682-1815," Annals of the Association of American Geographers 60 (1970), 428-46; John W. Reps, Town Planning in Frontier America (Columbia, MO, 1980); Carole Smith Zellie, "Nineteenth-Century Townsite Plans in Southern Wisconsin: A Typology and Analysis" (M.S. thesis, University of Wisconsin-Madison, 1989).

6. Conzen, "The Morphology of Nineteenth-Century Cities," 119.

7. Carl Sauer, "Historical Geography and the Western Frontier," in Land and Life: A Selection from the Writings of Carl Ortwin Sauer, ed. John Leighly (Berkeley, CA, 1963), 49. 
Sauer's assessment suggests that the ideologies of members of particular cultural groups dominated the process of frontier settlement. Unfortunately, however, it is difficult to establish direct links between individual planners of Iowa's county seats and antecedent urban planning traditions. Original town plats identify proprietors and surveyors, but neither they nor local historians have left us "accounts of the debates that must have set forth the advantages and disadvantages of the different proposals for the town plan, nor are we often told who drew the plans that were finally adopted or what models they sought to match or overshadow. ${ }^{\prime 8}$ Associations are complicated further by the sojourns of surveyors and proprietors into diverse culture regions where they were exposed to distinctive planning traditions before coming to Iowa. Thus, it is often difficult to trace the origins of forms of individual towns through their proprietors. Nevertheless, we can assess the impact of planning traditions on the general patterns of county seat forms by comparing them with the state's culture regions established during the settlement period.

\section{DETAILED POPULATION STUDIES of Iowa's settle-} ment patterns are lacking, but scholars have identified general migratory streams into the state. One of the earliest studies of Iowa's settlement history noted the strong southern influence prior to the Civil War, particularly in the field of politics during the territorial period. By 1860, though, less than 10 percent of Iowa's native-born population had been born in southern states. A more recent study by historical geographer John Hudson also suggests that the South's contribution to Iowa's settlement pattern was marginal. Hudson mapped and analyzed birthplace data of the earliest native-born immigrants to midwestern counties. His composite map of the Midwest shows that southern Iowa was predominately a zone of Midland culture settled by second-generation immigrants from southern and central Ohio and central Indiana, which had, in turn, been settled primarily by Pennsylvanians (fig. 3). On the other hand, second-generation Yankees who had been born in

8. Price, "The Central Courthouse Square," 29. 


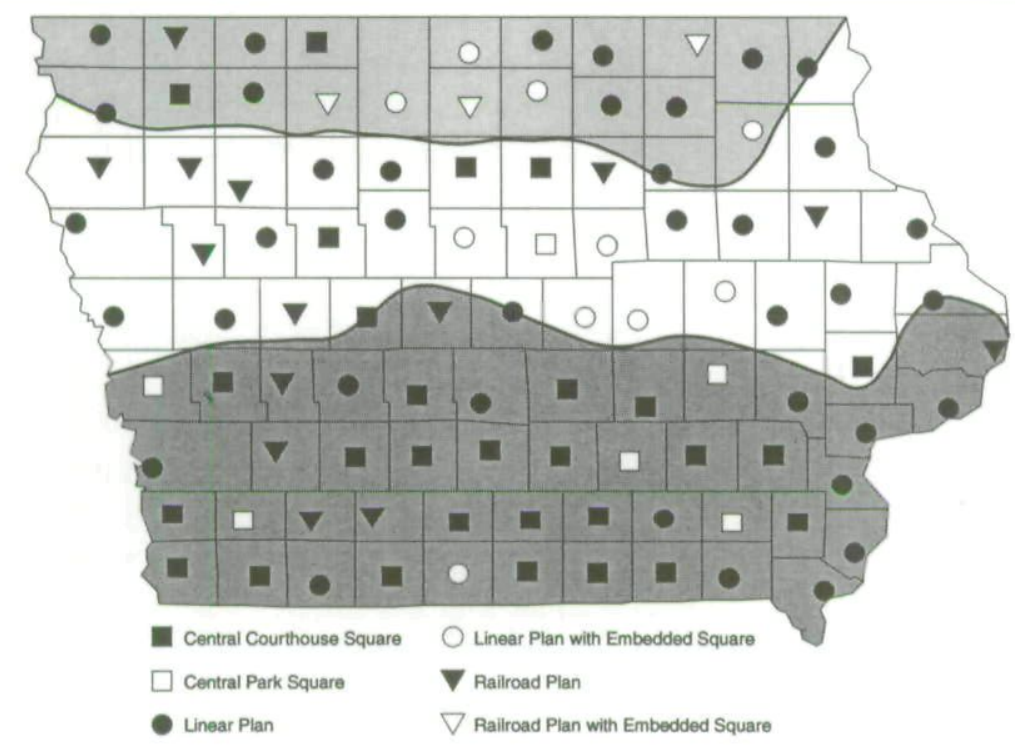

\begin{tabular}{lllll}
$0 \quad 25$ & $50 \quad 75$ & 100 & Miles \\
\hline
\end{tabular}

Fig. 3. Frontier forms of Iowa's county seats. Solid lines delineate culture regions based on birthplace data from John C. Hudson's 1988 article (see n. 9). Midlanders settled southern Iowa, whereas Yankees dominated in northern Iowa. Central Iowa comprised a mixed culture zone.

New York, and some of their sons and daughters who had been born in the Yankee country of southern Michigan and southwestern Wisconsin, settled the northern two or three tiers of counties in the late 1850s. Allamakee and Clayton Counties along the Mississippi River in northeastern Iowa were more easily accessible from the south and became an exception to this pattern of Yankee dominance of the northern tiers of counties. They belonged to a zone of mixed Yankee-Midland culture spanning the length of central Iowa in which Yankees generally settled later than Midlanders. This pattern fanned out in west central Iowa, where migration was aided by railroads. ${ }^{9}$

9. F. I. Herriott, "Whence Came the Pioneers of Iowa?" Annals of Iowa 7 (1906), 446-65; John C. Hudson, "North American Origins of Middlewestern Frontier Populations," Annals of the Association of American Geographers 78 (1988), 404-6, 411; idem, "Yankeeland in the Middle West," Journal of Geography 15 
PLANNERS OF IOWA'S COUNTY SEATS selected their designs from three principal classes of town forms: central courthouse squares, linear plans, and railroad plans. ${ }^{10}$ Twenty-eight of Iowa's ninety-nine county seats developed as central courthouse-square towns during their frontier periods. ${ }^{11}$ This number includes Mt. Pleasant, which evolved from a central courthouse square into a central park square forty years after its platting. It does not include a handful of central courthousesquare towns that lost county seat status with railroad development or others that did not develop according to their central courthouse-square plans. Fort Dodge exemplifies the latter situation. Its original plat shows a "Lancaster" square with streets intersecting the midpoints of each side of the square and slightly narrower business lots on blocks surrounding it. Although businesses dominated one side of the square by 1892, most businesses formed a linear business district east of the square on Market Street, whereas the public square eventually became a park.

Most county seats with central courthouse-square plans are located in the southern four tiers of counties; a solid core area of the form exists in south central Iowa (fig. 3). County seat forms in northern Missouri generally mirror this distribution.

(1986), 195-200. Hudson's boundaries generally reflect linguistic patterns across Iowa. Harold B. Allen, The Linguistic Atlas of the Upper Midwest, 3 vols. (Minneapolis, 1973-76), 1:122-40.

10. The classification of county seats is based on how the town developed in relation to its original plat during its frontier period, a time frame whose length varied from place to place but, for the purpose at hand, concluded when the town's business district and its public buildings became more permanently established after the initial period of town growth. I determined the location of business districts and public buildings from late nineteenth-century county atlases and from Sanborn Fire Insurance Company maps. I ignored original county seats that lost their status in the nineteenth century. Partly this was for simplicity, but the inclusion of new county seats also recognizes the dynamics of local and regional development.

11. Frederick Jackson Turner's definition of the frontier was based on counties with fewer than two people per square mile, but John Fraser Hart noted "the difficulty of trying to find a single definition, or cutoff value, that is equally applicable in all parts of an area as large as the Midwest." Frederick Jackson Turner, The Frontier in American History (New York, 1920); John Fraser Hart, "Facets of the Geography of Population in the Midwest," Journal of Geography 85 (1986), 201-10. 
The two regions collectively form the most concentrated area of central courthouse squares in the Midwest.

The pattern of central courthouse squares in Iowa correlates well with the Midland culture region in the southern part of the state. Only about 20 percent of Iowa's central courthouse squares are located north of the Midland zone, which is more or less coterminous with the southern four tiers of counties. Difficulties arise, though, when one tries to trace this association back in time. The nation's first central courthouse squares appeared in southeastern Pennsylvania, the cultural hearth that supplied much of the Midland stock that eventually settled southern Iowa. Courthouse squares are rare in Pennsylvania, however. ${ }^{12}$ Moreover, although central courthouse squares are more common along the path of the Midland culture stream in central and southern Ohio, they are not nearly as numerous there as they are in Iowa, and their geography lacks a discernible pattern. Only in central and southern Indiana does a salient clustering of midwestern central courthouse squares finally emerge. According to Hudson's birthplace data, however, most of that area's migrant stream was of Kentucky and Virginia stock-people more likely to have migrated to northern Missouri and contribute to the developing midwestern pattern of central courthouse squares there than in southern Iowa. Thus, although the distribution of central courthouse squares suggests an association with the Midland culture region in Iowa, causal linkages cannot be established through direct cultural lineage. Nevertheless, a valid cultural link between the two distributions is suggested by one of the systems of local government adopted in Iowa, and, more specifically, by its agents, the county commissioners who are identified as town proprietors on original plats of most central courthouse-square towns.

Iowa's territorial and state legislatures, like those of several other midwestern states, vacillated in the ways they adapted the systems of local government that emerged from the colonial period. Those systems ranged from the near total domi-

12. Pillsbury, "The Urban Street Pattern as a Culture Indicator"; Price, "The Central Courthouse Square." 
nance of the town in New England to the monopoly of the county in Virginia. When Iowa Territory separated from Wisconsin Territory on July 4, 1838, Iowa's territorial legislature adopted the county commissioner form of local government that had been introduced in Wisconsin Territory only four months earlier. In that system of local government, which originated in the Midland cultural hearth of Pennsylvania and diffused westward through Ohio and Indiana, the township was distinctive but largely in the shadow of the county, whose government was controlled by elected county commissioners. The legislation regulating township government in Iowa under this system also had Midland roots; it was adopted almost word for word from Ohio statutes. ${ }^{13}$

The Wisconsin territorial legislature, in the process of creating new counties, had designated county seats or authorized county elections whereby voters chose them. The fragile economies and contrasting locations of those early county seats made them vulnerable to rival factions who advocated either centralized locations with their egalitarian accessibility, or peripheral river sites that had greater potential for interregional commercial development. These conflicts may have prompted Iowa's territorial legislature to seek a more democratic system for locating county seats. ${ }^{14}$

On January 15, 1839, the legislature appointed commissioners from adjacent counties to locate the county seat of Linn County, thereby instituting a procedure for locating county seats that was to continue until the end of the era of county formation in the state. The language of authorization acts for individual counties varied, but generally, locating commissioners swore before a judge that they would faithfully and impartially locate the county seat while considering the natural resources of potential sites as well as the present and

13. Clarence Ray Aurner, "History of Township Government in Iowa" (Ph.D. diss., University of Iowa, 1914), 24-36. For surveys of systems of local government, see John A. Fairlie, Local Government in Counties, Towns, and Villages (New York, 1906); Kirk H. Porter, County and Township Government in the United States (New York, 1922); and Paul W. Wager, County Government across the Nation (Chapel Hill, NC, 1950).

14. Aurner, "History of Township Government in Iowa," 24-36. 
future population of the county. ${ }^{15}$ As locating commissioners canvassed the newly formed county, they were sometimes accompanied by town proprietors and landowners who lobbied for the merits of their site. As a rule, however, locating commissioners chose neutral sites with a moderate to high degree of centrality. ${ }^{16}$ The significance of the implementation of this act is that after 1839 it discouraged the selection of existing places as county seats, particularly those with peripheral locations along rivers that typically had linear plans with a commercial focus.

Accompanying the legislation that authorized the location of the Linn County seat was a second act that further strengthened the hand of local government in county seat formation. In part, the second act required county commissioners, or any other persons who wished to lay out a town in the territory, to have the proposed townsite surveyed. The county surveyor then had to create a representative map or plat. ${ }^{17}$ Although the act allowed private individuals to plat county seats, county commissioners dominated the process from the time the act was approved until 1851, when the form of local government in Iowa was changed to the highly centralized county judge system. During that twelve-year period, the legislature organized twenty-two counties, nineteen of which established county seats. County commissioners platted seventeen of those nineteen seats: eleven with central courthouse squares, three with park squares, and three with linear plans.

The platting of the early county seats came quickly after county organization. Chariton, county seat of Lucas County in south central Iowa, is a case in point. Lucas County was organized under an act of the Second General Assembly approved January 15, 1849. In August 1849 county voters elected county commissioners. Locating commissioners fixed the county seat within a mile of the center of the county and filed their re-

15. See Documentary Material Relating to the History of Iowa, ed. Benjamin F. Shambaugh, 3 vols. (Iowa City, 1895-1901), 3:46-66.

16. For a discussion of the geography of centrally located county seats, see Richard V. Francaviglia, "County Seat Centrality as a Regional Trait," Geographical Survey 2 (1973), 1-21.

17. Revised Statues of the Territory of Iowa (Iowa City, 1843), 607-10. 
quired report on September 11, 1849. Although the county did not secure official title to the land on which the county seat was located until October 10, 1851, county commissioners anticipated the purchase of a military land warrant and so set about the business of founding Chariton. On September 12, 1849 , they appointed William S. Townsend to survey the townsite and to sell lots, which were eventually offered for public sale on the first Monday in November 1849. Thus, less than a year transpired from the time the county was organized until town lots went on sale. ${ }^{18}$ In most counties organized during the twelve-year period in which county commissioners dominated town-founding processes, the framework of local government was established in a similar time span, leaving little opportunity for private townsite ventures.

Planners of Iowa's county seats used a variety of central courthouse-square plans, including Shelbyville, Lancaster, fourblock, and double squares. The Shelbyville plan, consisting of a courthouse centered within a square block surrounded by more than half of the principal business district, was by far the most popular (fig. 4). ${ }^{19}$ Twenty-two of Iowa's county seats have Shelbyville squares. Chariton is typical (fig. 5). The original plat consisted of sixteen outlots, a public square, and nineteen regular blocks, each with eight lots. Business lots were undifferentiated by size but oriented to the square. County commissioners authorized a townsite agent to conduct a public sale of lots. A second agent, also appointed by the commissioners, sold remaining lots from time to time, and the money accrued from their sale went into the general operating fund of the county. In Chariton, at least, the county government remained involved in the process of town development well after the initial platting of the town.

Plans of the commissioner towns of Adel, Bloomington, Clarinda, Knoxville, Montezuma, Newton, Sigourney, Washington and Winterset were much like that of Chariton: Shelby-

18. A. T. Andreas, Illustrated Historical Atlas of the State of Iowa (Chicago, 1875), 495; History of Lucas County, Iowa (Des Moines, 1881), 401-7. Because the town had to be replatted, its official plat actually dates from May 3, 1850.

19. Price, "The Central Courthouse Square." 


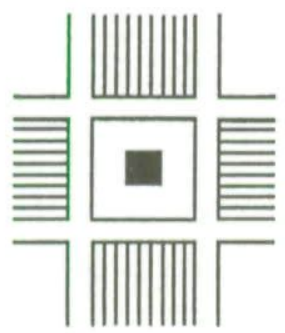

Shelbyville square

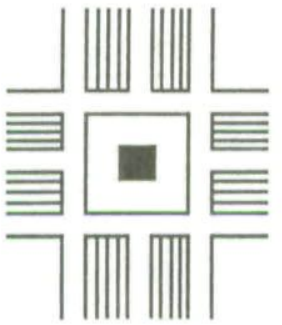

Four-block square

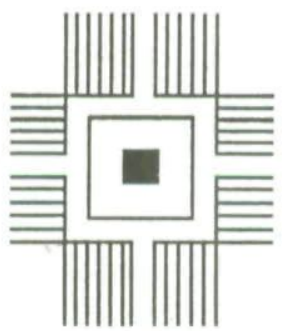

Lancaster square

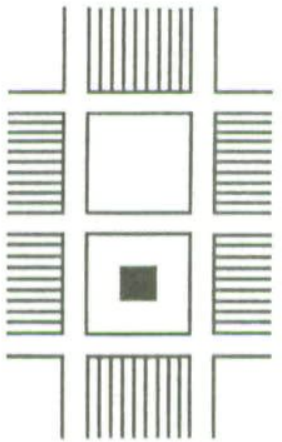

Double square

ШШШ Business lots facing the courthouse square

Fig. 4. Plans of courthouse squares in Iowa. Modified from Edward T. Price's 1968 article (see n. 5).

ville squares with a standard eight lots in both residential and business blocks with business lots oriented to the square. Only the size of the plats varied. Planners of other Shelbyville square towns, such as Albia, Indianola, Mt. Ayr, Primghar, and Tipton subdivided their blocks into more lots. The plan of Indianola, platted by commissioners Joel Scott and David Barker, was by far the most ambitious of these. Each of its twenty-four blocks has twenty-four lots, a rare example of block subdivision more commonly associated with townsite speculation in later railroad and linear towns. 


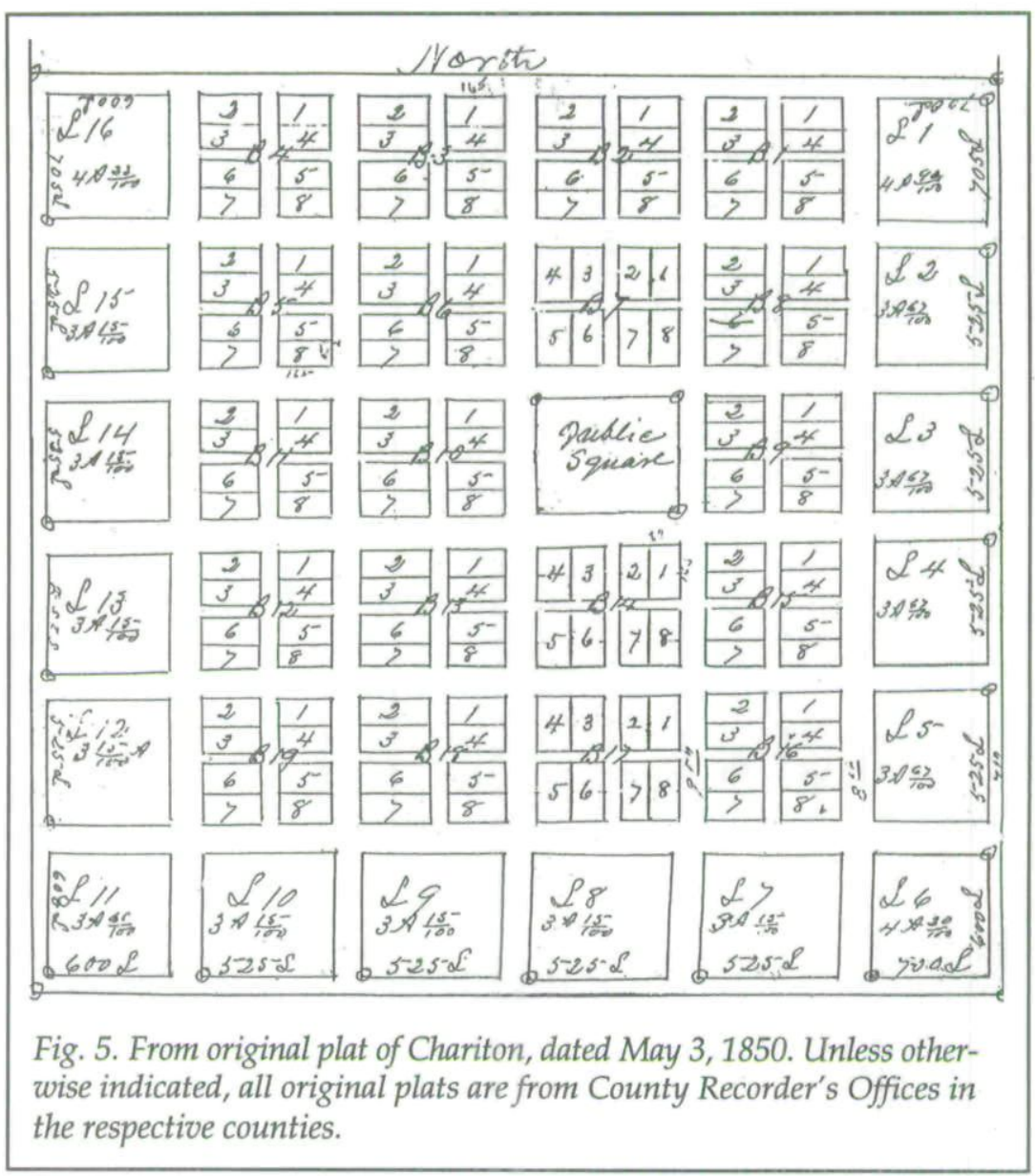

Town proprietors platted four double squares in Iowa. The prototype double square consists of a courthouse block and an adjacent open block both surrounded by the principal business district. The open block was usually reserved for a park. Only the double squares of Hampton and Sidney survived the early period of development, and only Hampton had a symmetrical double-square plan. Proprietors platted three four-block squares as county seat towns in Iowa, but only two, Centerville and Corydon, survived beyond the early period of town development. Estherville's planners designed it as a four-block square, but it evolved into a double square. 


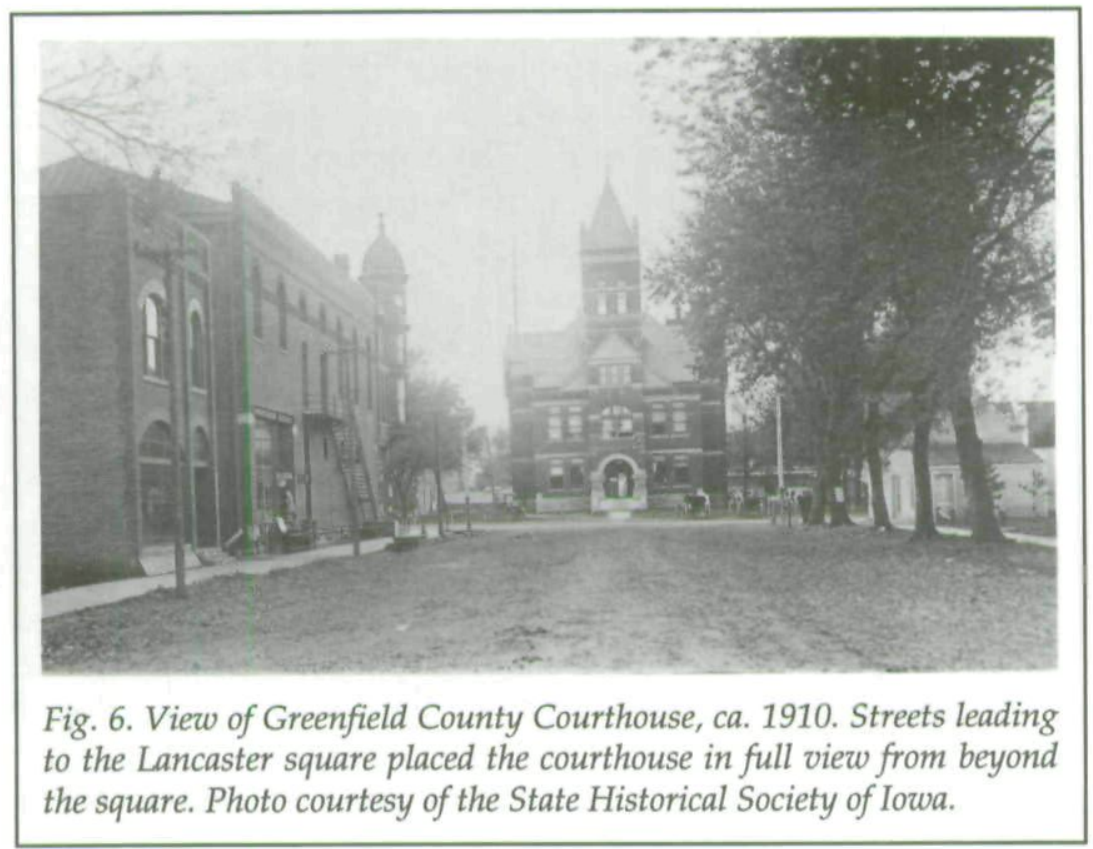

Even more rare was the Lancaster square (fig. 6). This plan consists of a courthouse centered on a block with streets intersecting the midpoint of the sides of the block. Only one Iowa county seat, Greenfield, in Adair County, developed as a Lancaster square. Milton and Mary Munger platted Greenfield, but the county surveyor, D. M. Valentine, may have been responsible for its design. Valentine grew up in Ohio, and he had lived in Illinois, two states in which Lancaster squares were more numerous. Greenfield's Lancaster square was one of the last platted in this part of the Midwest.

SIX COUNTY SEATS in Iowa developed as central park squares. County commissioners platted three of these county seats within the core area of central courthouse squares in southeastern Iowa. It seems unlikely that commissioners designed them as central park squares, because their original plats are very similar to those of courthouse square towns, and because the commissioners did not stipulate that their squares were to be reserved as parks. Although it was a common prac- 
tice for public squares to remain open for some time after their platting, a "permanent" courthouse, usually a two-story wood or brick structure, was built on the square as counties grew in population and wealth. During the interim, county officials operated out of rented rooms in early businesses or crude log or frame courthouses. In central square towns these temporary structures were usually located on a side of the square.

Central park squares evolved differently in the commissioner towns of Fairfield, Marengo, and Oskaloosa. The case of Fairfield, county seat of Jefferson County, rests on strong opposition by townsfolk to construction on the public square. County commissioners advocated building, but the opposition obtained a court injunction against construction on the square, and the courthouse was eventually built on lots away from the square. ${ }^{20}$ The historical record does not clearly identify the factors influencing the evolution of the forms of Oskaloosa and Marengo, but in both cases delayed construction of large permanent courthouses probably promoted the evolution of the central square into a park square.

Individual proprietors platted three other county seats whose forms evolved into central park squares: Logan in Harrison County, Red Oak in Montgomery County, and Eldora in Hardin County. Logan developed as a central park square largely because its proprietor, Henry Reel, decreed that the public square on the original plat was to remain a park. In deference to Reel's stipulation, the county placed the courthouse on a square in Long's Addition west of the original town. ${ }^{21}$

Railroads influenced the location and growth of Red Oak in southwestern Iowa. After citizens voted to relocate the county seat to Red Oak, Montgomery County officials eventually paid a hotel owner two thousand dollars for eight lots of Block 39 for the new courthouse. The issue of the courthouse location was finally settled after the remaining lots of that block were donated on the condition that a courthouse be erected there. ${ }^{22}$

20. Fairfield Ledger, 17 August 1881.

21. Logan Centennial, 1867-1967 (Logan, [1967]), 11.

22. W. W. Merritt, A History of the County of Montgomery (Red Oak, 1906), 153-56; Montgomery County Centennial Committee, Montgomery County Courthouse Centennial, 1890-1990, 15-25. 
Eldora, platted in July 1854 by James and Erwina Drain, emerged from its frontier period as a central park square. Its first courthouse and jail were located on the east side of the town square. A. T. Andreas, in his description of the town's core in 1875, noted that a "public park has been laid out in a central position, around which most of the mercantile business is transacted in accordance with the arrangements of many western towns." Eldora's location about seven miles east of the county center left its political flanks open to attack in ensuing county seat wars. The last one, fought in the early $1890 \mathrm{~s}$ with Iowa Falls, a town in the north central part of the county, concluded when Eldora's citizens provided about forty thousand dollars in subscriptions for the construction of a new courthouse. $^{23}$ That effort made Eldora the only county seat in Iowa whose form converted to a central courthouse square after its frontier period.

FROM 1851 UNTIL 1860, when the legislature introduced the board of supervisors system, county judges controlled local government in Iowa. As individual representatives of local government, county judges exercised far less control over county seat formation in the 1850 s than did county commissioners during the 1840 s. County judges platted only about one-fourth of the forty county seats established during the decade, and only five of those-Clarinda, Corydon, Hampton, Jefferson, and Mt. Ayr-evolved as central courthouse-square towns.

The 1850s, therefore, represented a transitional period in urban planning in Iowa, as the control over county seat formation shifted from county commissioners to county judges and thence to private individuals and corporations, engendering a variety of frontier urban landscapes. The founding of Mt. Ayr, county seat of Ringgold County, exemplifies county seat formation in this transitional period. According to the surveyor's statement on the original plat, the county judge, James C. Hagans, and John S. Sheller, the owner of the eastern half of the section comprising the original townsite, furnished Mt.

23. Andreas, Historical Atlas, 485. 


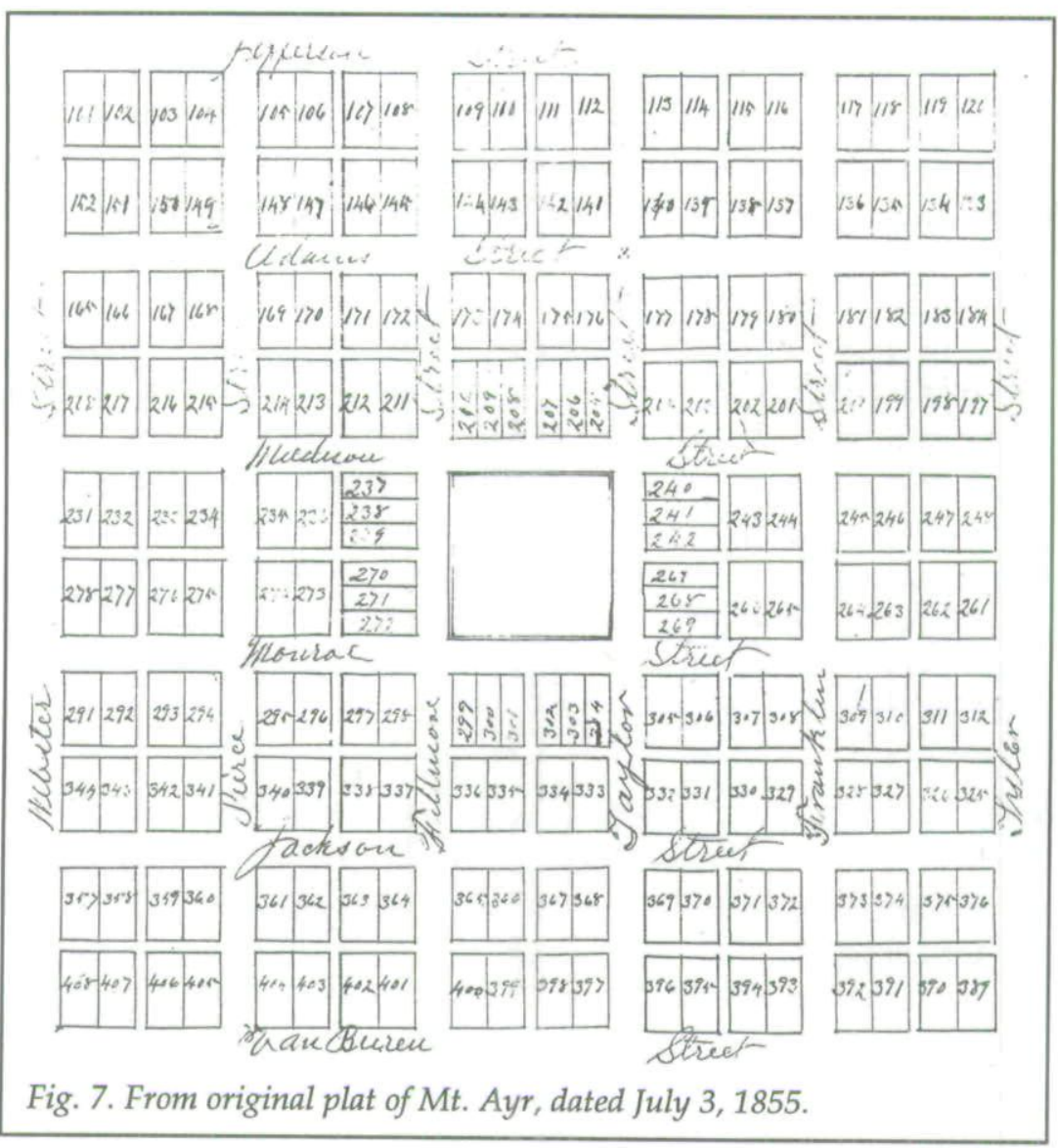

Ayr's plan (fig. 7). Although the county acquired the eastern half of the townsite from Sheller, Edward and Jane Temple retained ownership of the western half and platted the town jointly with Hagans in July 1855. One historian of the period, while lamenting the increasing role of the land speculator in western Iowa, suggested complicity in the location of the county seat between location commissioners and speculators, presumably the Temples. The early growth pattern of the town reflected that speculative influence. By the mid-1860s, the eastern half of the townsite, including the eastern half of the central square, was a "neat little country town," whereas the western half, ostensibly held from the market as lot values 
escalated, was an "open prairie, without a house, fence, or tree upon it." ${ }^{24}$

The town evolved according to its plan as a Shelbyville square, but the collaboration of private speculators with the county government signified diminished political control over county seat formation and, in time, a concomitant demise of politically determined town forms. Although individual proprietors also platted central courthouse-square towns after 1851, they platted only two of their total of eight after 1858. Their plan of choice was increasingly linear. By the late 1850s, the heyday of the central courthouse square in Iowa was over.

\section{ABOUT HALF OF IOWA'S COUNTY SEATS have linear} plans. Popularly known as main street towns, linear plans feature businesses facing each other along a single street of the grid. The core area of linear county seats in Iowa is the northeastern quadrant of the state, but the plan is also important in northwestern Iowa (see fig. 3). The pattern of linear county seats correlates fairly well with the Yankee culture zone in the northern two tiers of counties. Throughout Yankeeland the commercial district, not the courthouse, was the focus of the town. ${ }^{25}$ In the Yankee-Midland mixed culture zone of central Iowa, however, central courthouse squares remained a formidable ideological competitor of linear town plans during the immediate post-commissioner period.

Iowa's first county seats were linear towns that sprang up along the Mississippi River prior to the creation of Iowa Territory in 1838. To protect their claims from rivals, town proprietors of Dubuque (ca. 1833), Burlington (1833), and Fort Madison (1835) had their townsites surveyed into streets and blocks without title to the land. As a result, Congress authorized an official survey that provided for the surveyor general of the public lands to lay off these townsites into "town lots, streets, avenues, and the lots for public use called the public squares, and into out-lots, having regard to the lots and streets already

24. Charles A. White, "Some Characteristic Features in the Early and Present History of South-Western Iowa," Annals of Iowa, first ser., 5 (1867), 838.

25. Hudson, "Yankeeland in the Middle West," 199. 
surveyed, in such manner and of such dimensions as he may think proper for the public good and the equitable rights of the settlers and occupants of the said towns."

Because the act also stipulated that a "quantity of land of proper width" adjacent to the river was to be retained for public use, the early Fort Madison business district was removed from what was considered to be a prime location on the fractional lots between Front Street and the river to Second Street one block north of and parallel with the river. ${ }^{27}$ This business district geography was the most common design for midwestern river towns because it made their entire business districts more accessible to river traffic, and, where necessary, it allowed for the expansion of commercial space along level floodplains. Fewer river towns developed as Burlington and Dubuque did, with linear business districts projecting away from the river. In some of those townsites, terrain and river meanders precluded parallel orientation of business districts to the river; in others, the location of a ferry crossing or early bridge funneled traffic to the "head" of the business district and progressively away from the river.

Despite their peripheral locations within their counties, county seat status was inevitable for Mississippi River towns such as Davenport, Dubuque, and Burlington, whose locations generated growth that outstripped that of rivals. ${ }^{28}$ In Allamakee, Clayton, and Jackson Counties, though, voters chose inland towns for their county seats after two decades of electoral conflict.

In Jackson County the struggle was between Bellevue, the original county seat on the river, whose environs had achieved some notoriety as a warren for outlaws, and Andrew, the commissioner county seat located near the county center, whose name complemented that of the county. Bellevue became the county seat in 1837, lost it to Andrew in 1848, regained status in 1851, and lost it again to Andrew in 1861. It was Maquoketa,

26. United States Statutes at Large, vol. 5, 70-71, quoted in "Some Beginnings in Iowa," Iowa Journal of History and Politics 28 (1930), 30.

27. Hawkins Taylor, "Recollections of Thirty-four Years Ago," Annals of Iowa, first ser., 8 (1870), 334.

28. Mahoney, "Urban History in a Regional Context." 
though, in the southeastern part of the county that fired the final salvo in the conflict. Platted in October 1850 by early homesteaders of the area, Maquoketa became the county seat in 1873, shortly after acquiring the Iowa Midland Railway during the postwar boom period of railroad construction in Iowa. ${ }^{29}$ With the arrival of the railroad more than twenty years after it was platted, Maquoketa's linear business district on Main Street remained entrenched at the western edge of an asymmetrical original plan that had little in common with most county seat plans in Iowa. Nearly all of the rectangular blocks had at least fourteen lots, and Livermore and Spalding Squares, named after two of the original proprietors, were opposite each other on the east and west margins of the plat. Although Maquoketa's design lacked the accoutrements of an Iowa county seat, the railroad powers prevailed and it became one anyway.

The establishment of the seat of local government in Jackson County was smooth sailing compared to that in Clayton County, where the location of the county seat changed six times before 1860. In that year, Elkader, platted by John Thompson in 1846 along the Turkey River, finally won its county seat war with the commissioner town of Garnavillo. Both towns were located within five miles of the county's center, so neither had the advantage of a central location. Likewise, neither had a railroad before the issue was settled by the electorate. The principal river town of the county, McGregor, never competed seriously for county seat status, probably because it was tucked away in the northeastern corner of the county, more than fifteen miles from the county's center. ${ }^{30}$

Elkader's original plan was more typical of linear county seats platted along the state's rivers than was Maquoketa's (fig. 8). Like plats of central courthouse-square towns, Elkader's original plat shows eight lots per block, but it lacks a public square for the courthouse because the town was never a serious contender for county seat status until it acquired a railroad twenty-five years after platting. Despite the location of Main Street perpendicular to the river and at the end of an

29. Andreas, Illustrated Historical Atlas of the State of Iowa, 443-44.

30. Ibid., 435-37. 


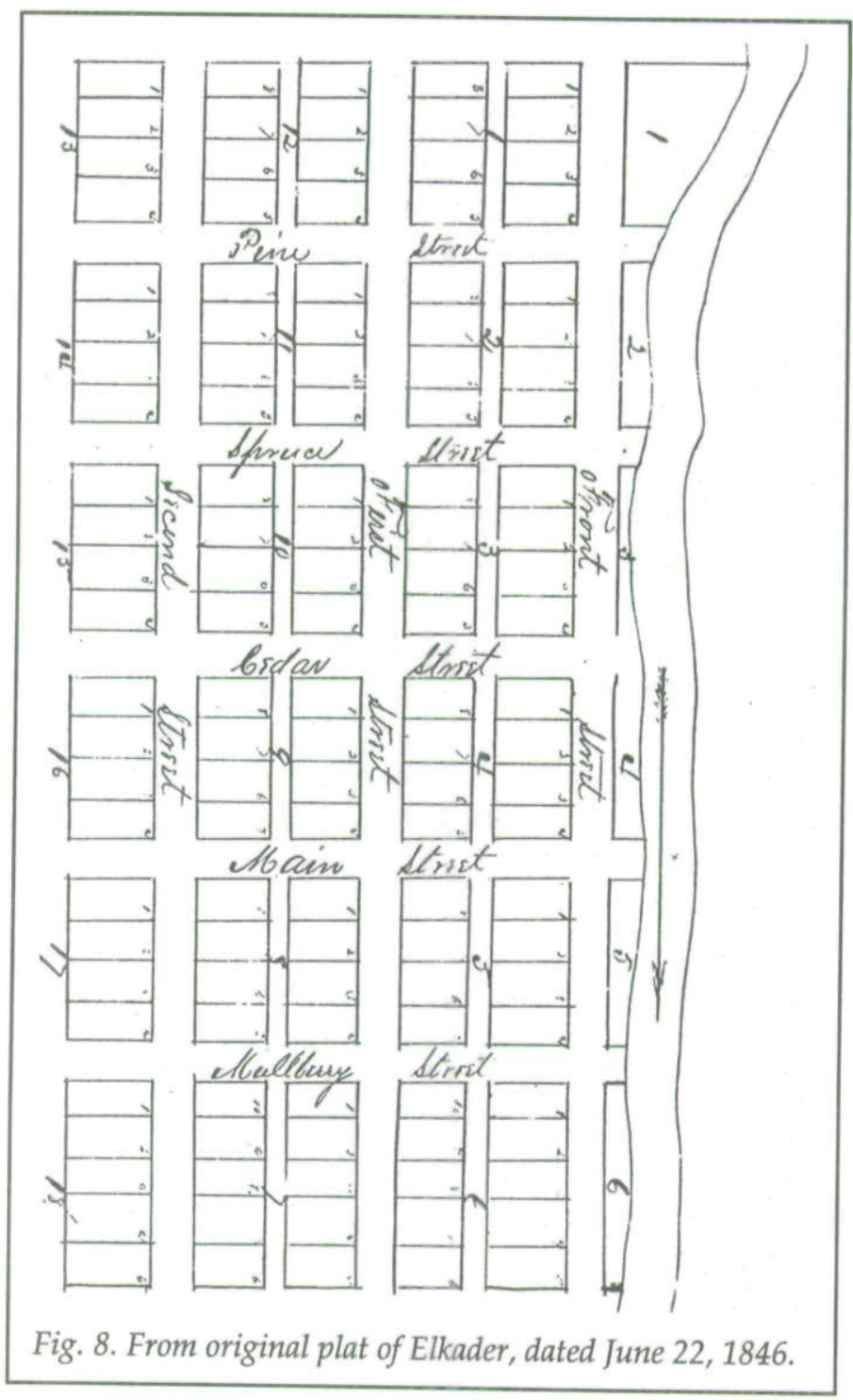

access bridge, the business district developed along Front Street parallel to and west of the river, where the topography of the floodplain was more suitable. The courthouse was eventually located in an addition opposite the business district on the east side of the river. 
County commissioners also platted linear towns, including Wapello in Louisa County (1839), Ottumwa in Wapello County (1844), and Iowa City in Johnson County (1839). These exceptions to the pattern of association between county commissioners and central square plans are due partly to timing and partly to quirkiness.

Wapello's original plat, dated May 6, 1839, is oriented to the Iowa River. Its asymmetrical design created only partial lots on one side of a public square that was located at the intersection of the town's two broadest streets. The linear business district developed in England's Addition (Upper Wapello) north of the original town along Second Street parallel to, and one block from, the river. Commercial river traffic and the awkward shape of lots around the square probably influenced the location of the business district. At least for a short time, steamboats sailed the Iowa River beyond Wapello to Iowa City after it became the territorial capital.

Ottumwa's history began with a group of eleven townsite speculators who formed the Appanoose Rapids Company on May 20,1843, shortly after the expiration of Indian title to the land comprising the townsite, and about one year before locating commissioners selected Ottumwa as the county seat of Wapello County. Prior to county organization in 1844 and shortly after organization of the company, investors shrewdly placed their townsite within a half-mile of the county center because they knew that Wapello County and others within its tier were to be $18 \times 24$ miles, the same size as Jefferson County immediately to the east. By May 1843, John Arrowsmith, a surveyor hired by the company, had completed a partial survey of the townsite at the "Appanoose Rapids" of the Des Moines River. As an inducement for locating the county seat at Ottumwa, the company offered to the county every alternate lot of the townsite up to a maximum of 160 acres. ${ }^{31}$ The newly elected county commissioners, perhaps sold on the townsite because of its centrality and available water, agreed to the proposal and platted the town jointly with the townsite company. The county surveyor, Hugh George, either

31. History of Wapello County, Iowa (Chicago, 1878), 461-67. 
resurveyed the townsite or completed the survey begun by Arrowsmith. Ottumwa, however, developed in the familiar pattern of a river town, with a linear business district on Second Street parallel with, and one block from, the river.

Iowa City's linear plan emerged under a different set of circumstances. The territorial legislature organized the county on December 21, 1837, and placed it under the jurisdiction of Cedar County. A second act of organization, approved on June 22,1838 , established the seat of justice at Napoleon, a town laid out by two early settlers. After the legislature authorized county commissioners to relocate the county seat on December 21,1839 , Napoleon faded quickly into obscurity. On November 1,1838 , the legislature authorized commissioners Robert Ralston, John Ronalds, and Chauncey Swan to locate the territorial capital. They selected the site of Iowa City in May 1839 and platted the town on July $4 .{ }^{32}$ Because Iowa City became first the seat of territorial, not county, government, it was platted by locating commissioners, not county commissioners. Its original plan shows a four-block capitol square and several other squares, but, of course, it lacks a specified courthouse square (fig. 9). A linear business district developed along Washington Street on the south side of the capitol square and spread quickly to lateral streets. The courthouse was eventually located on a square in an addition south of the original town.

About half of Iowa's county seats with linear plans are traditional main street towns oriented to the cardinal directions and with the courthouse square either on the perimeter of the business district or displaced from it by residential area. Bedford, the county seat of Taylor County in southwestern Iowa, is a typical linear plan of this type (fig. 10). Commissioners from adjacent counties located the townsite in 1853, but it was not until 1856 that a small group of landowners officially platted the town. Whoever was responsible for the town plan, the town's business district developed according to it along Main Street one block south of the public square upon

32. Andreas, Illustrated Historical Atlas of the State of Iowa, 477; William J. Petersen, The Story of Iowa: The Progress of an American State, 4 vols. (New York, 1952), 319-21. 


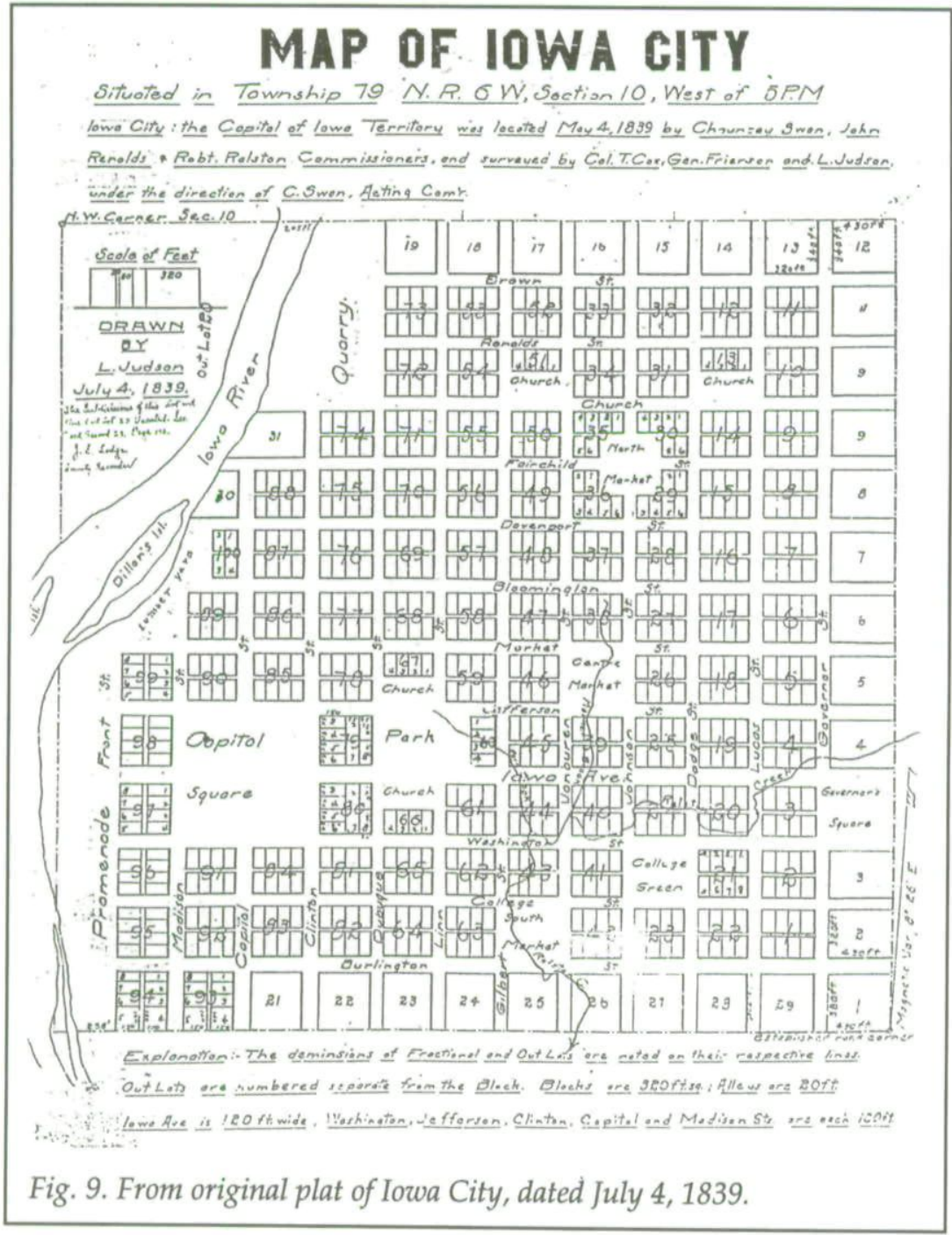

which the courthouse eventually found a permanent home. Bedford's design was typical of inland county seat towns with linear plans, but atypical for those in a part of Iowa dominated by central courthouse squares. It was a plan, though, that was soon to dominate linear town forms in Iowa and elsewhere.

In the Yankee-Midland mixed culture zone, a hybrid of linear and central courthouse square plans, the embedded square, 


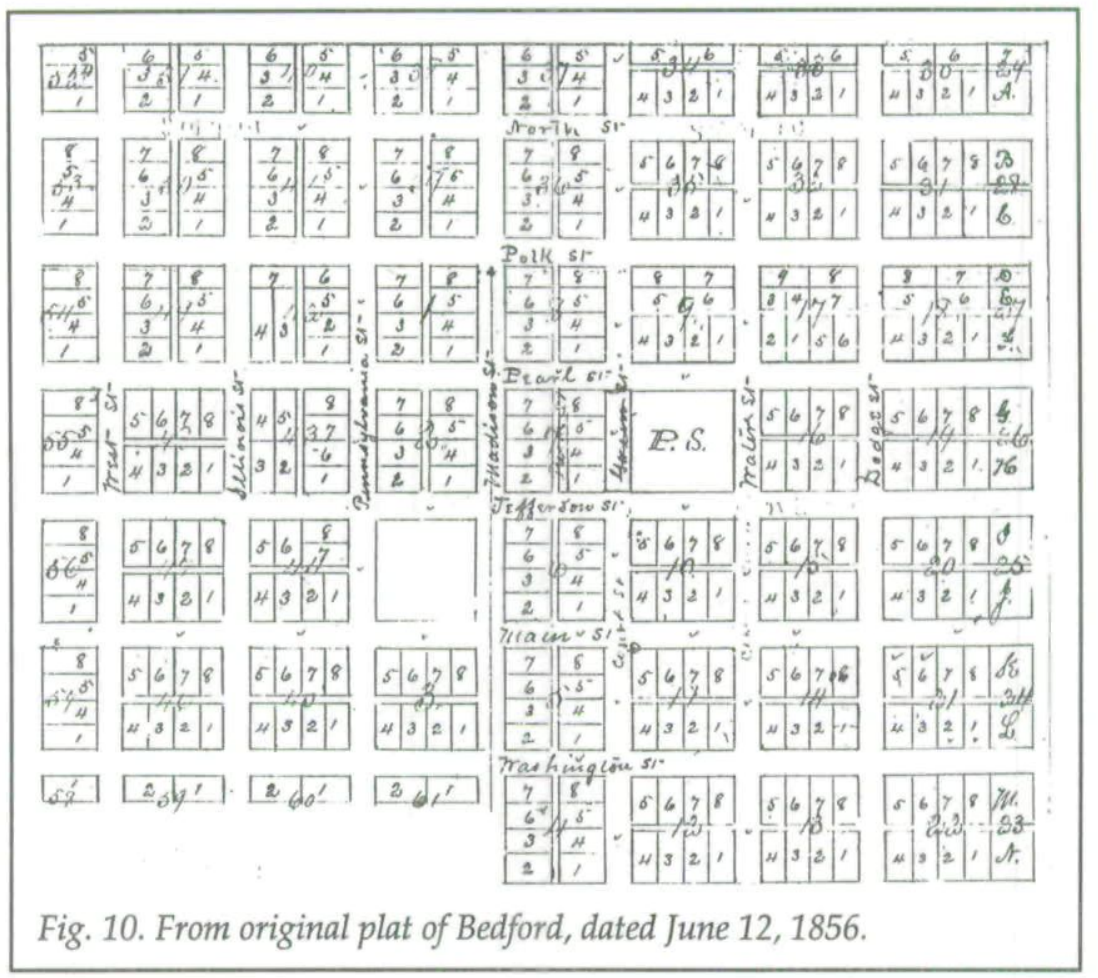

evolved in the 1850s. In these county seats, one side of a courthouse square was fully integrated into what was essentially a linear business district. Such plans were popular in midwestern states east of Iowa. Many of the original plats of embedded square towns are central courthouse-square designs, but the towns developed differently. Economic forces, active in the initial stages of town development, often pulled businesses away from the square and down a side street that may or may not have been designed for businesses.

Other embedded square towns, such as Grundy Center in Grundy County, developed from linear town designs (fig. 11). The courthouse square was definitely part of the town core, but the plat indicates that proprietors never intended for Grundy Center to develop as a central courthouse square town because the lots of the blocks east and west of the square are not oriented to it. Moreover, the greater width of Main Street suggests that it was intended to handle more traffic than streets around 


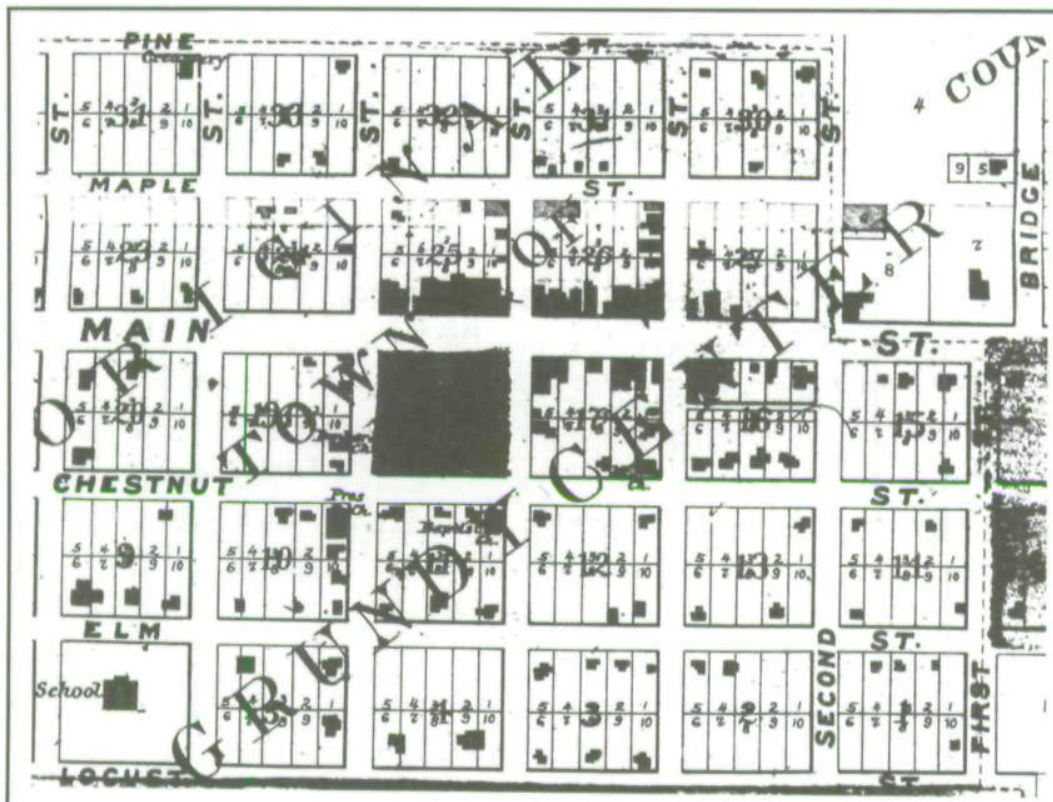

Fig. 11. From atlas plat of Grundy Center, showing the courthouse square as part of a linear business district. From Plat Book of Grundy County, Iowa, 1884 .

the square. Also, the presence of three churches on lots south and east of the square suggests that those lots were originally donated, something proprietors would seldom do if the lots were designated for businesses and could therefore command high market prices.

RAILROADS, their affiliated companies, and private individuals connected with them rapidly became important forces in the platting of county seats across Iowa beginning in the mid-1850s. ${ }^{33}$ More than half of the county seats that were influenced by railroad development are located in the northwestern quadrant of the state (see fig. 3). The Iowa Constitution severely limited state spending for railroad construction, so local aid, in the form of bonds issued by county gov-

33. Bryant, Preliminary Guide to Iowa Railroads. 
ernments, became attractive alternative sources of funding. ${ }^{34}$ County judges were caught in the middle between the desires of overly zealous county citizens, who often voted in favor of bonds without adequate safeguards, and some unscrupulous railroad officials who were unwilling to fulfill the conditions of their agreements. When the inevitable conflicts arose, there was no standardized legal code governing the uniformity of the bonds and ultimately the course of conduct between the corporate and public interests. Although county judges "usually received broad discretionary power to decide when conditions imposed by the people had been fulfilled, and, consequently, the exact time that the bonds were to change hands and the circumstances under which the transfer would take place," they were relatively powerless to control the logistics of railroad construction within their counties. ${ }^{35}$ Even stipulations attached to federal land grants could not always determine precisely where a railroad would be built.

Within this context, at least two factors were to have a significant impact on urban morphology and the nucleated settlement pattern in Iowa. At the local level, railroads tried to minimize construction costs by exploiting advantages of terrain, such as stream floodplains and terraces. These natural avenues for track did not always lead to the vicinity of centrally located county seats established by commissioners. As a result, county seats were sometimes bypassed. A more important factor, though - and one that operated in conjunction with the idea of advantageous terrain-was the ability of the railroads to engender nucleated settlements along their routes. Railroads were such a magnet for commerce that new towns appeared on rail lines everywhere in Iowa, and they influenced either directly or indirectly the location of at least twenty county seats. Ironically, in their effort to secure railroads for their counties, voters in some Iowa county seat towns passed bond issues for railroad construction that inadvertently caused the demise of their towns when their county seats were relocated to a railroad route.

34. Earl S. Beard, "Local Aid to Railroads in Iowa," Iowa Journal of History 50 (1952), 1-2.

35. Ibid., 6 . 


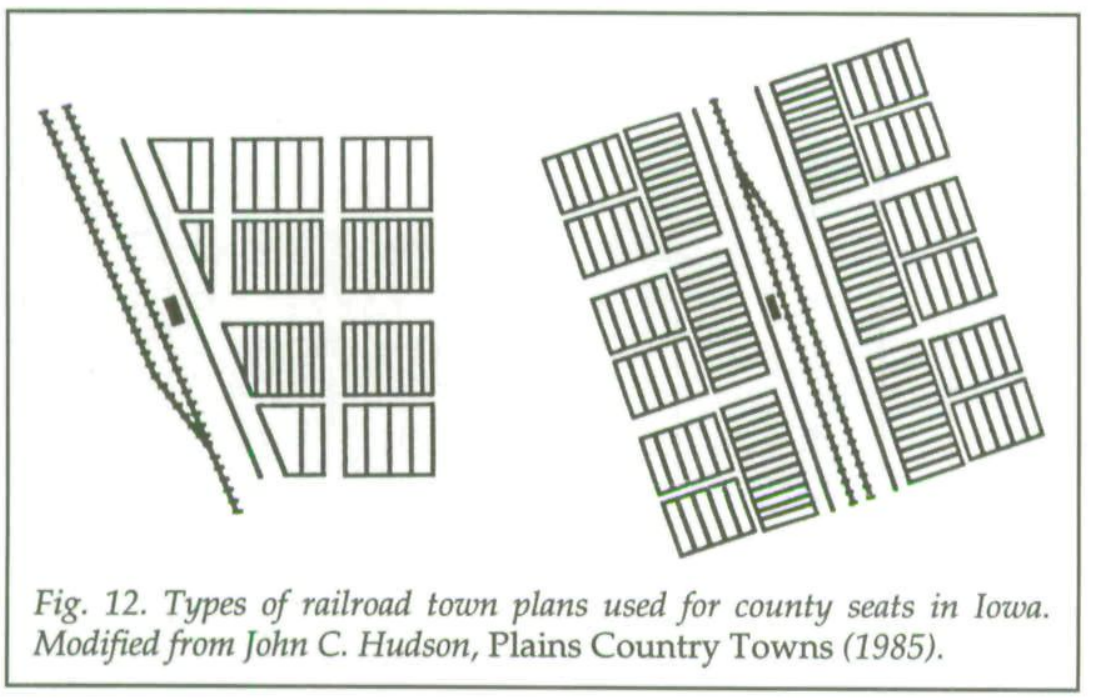

Nearly all of the county seats with railroad town plans in Iowa developed a linear business district that formed a Tshaped configuration with the tracks. Railroads or affiliated companies platted the most standardized of these T-town forms with streets conforming to the orientation of the tracks rather than to the cardinal directions (fig. 12). Iowa county seats with T-town plans were rarely standardized, however, because many were platted by individuals and because standardized T-town designs had to compete with ideological assumptions that the central courthouse square was the ideal form for a midwestern county seat.

Clinton, platted by the Iowa Land Company in 1855 along the Mississippi River, was the first of several Iowa railroad towns to gain county seat status at the expense of more centrally located places. Unlike other Iowa towns along major rivers, nearly all of which developed linear plans, Clinton was founded as a railroad town. It came into existence shortly after T. T. Davis, representing eastern financiers, including Erastus Corning, president of the New York Central Railroad, came to Iowa to find good investment land and to survey a bridge site across the Mississippi. The bridge was to connect Fulton, Illinois, railhead of the Dixon Air Line of the Galena and Chicago Union Railroad, with a projected line across Iowa. To the dis- 
may of promoters of the prosperous townsite of Lyons, located on the west bank of the river opposite Fulton and just north of the Clinton townsite, Davis, who was also one of the directors of the Iowa Land Company, recommended the site of Clinton for the proposed bridge. ${ }^{36}$

The site of the proposed bridge was a great advantage to Clinton because it ensured investment by eastern capitalists operating through the Iowa Land Company. According to a company circular published three years after its incorporation, the Iowa Land Company was formed "to purchase lands within the state, and especially at various points along the line of a railroad which its corporators and stockholders had projected, from the Mississippi river, into the interior (eighty-one miles) to Cedar Rapids, and to hold the same for the purpose of selling them to actual settlers, upon such liberal terms, both as to price and time, as to induce the more complete and speedy development of the resources of the country along the whole line of the railroad which they had projected, and, by these means, to increase its business and enhance its profits. ${ }^{\prime 3}$

Clinton's original plat shows blocks and streets oriented to the Mississippi and Iowa Central Rail Road, an ephemeral line based in Lyons that, lacking financial support from the land company, quickly collapsed after engineers had graded only a half-mile west of Clinton. The successor to the Mississippi and Iowa Central, the Chicago, Iowa and Nebraska Railroad, backed by capital from the Iowa Land Company, completed construction to Cedar Rapids by June 1859. The company circular described the relationship between the Iowa Land Company and the railroad as "entirely distinct and independent, yet in view of the large interests which the stockholders of the former have in the latter, the policy of the Land Company has been, and is such, as to offer every reasonable inducement to those whose business may, in any way, contribute to the revenue of the road, or serve to increase the value of the lands they may possess. ${ }^{138}$ That policy involved construction of the Iowa

36. History of Clinton County, Iowa (Chicago, 1879), 488-89.

37. A Brief Circular, Relating to the Counties of Clinton, Cedar and Linn, in the State of Iowa (Chicago, 1858), 9.

38. History of Clinton County, 493-94; Brief Circular, 13. 


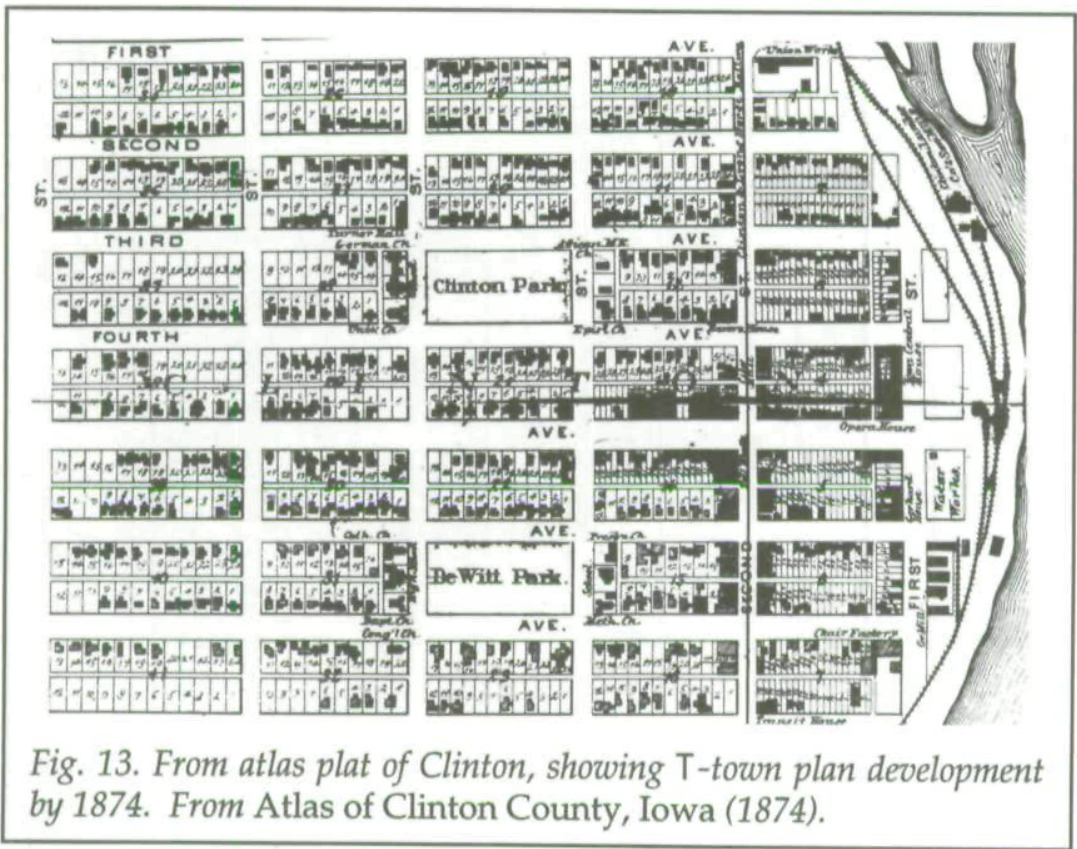

Central Hotel to accommodate railroad passengers and the naming of two parks in the central portion of the plat after De Witt Clinton, then governor of New York.

At the time of its platting, De Witt was the Clinton County seat. In October 1869, however, in the wake of Clinton's postCivil War building boom, Clinton lured the county seat away from its central county location. An 1874 atlas view shows that Clinton developed as a cross T-town, with most businesses arrayed on Fifth Avenue (fig. 13). A local historian of the late nineteenth century remarked that on "Second Street and Fifth Avenue wooden blocks and stores rose like an exhalation., ${ }^{\prime 39}$ Meanwhile, the courthouse, arriving on stage fifteen years after the town's opening act, was relegated to Block Eight of Clinton's North Addition.

Prior to the construction of railroad lines in Iowa, planners had already introduced standardized railroad town designs, including the symmetrical town plan, in Illinois. In towns with

39. History of Clinton County, 490. 


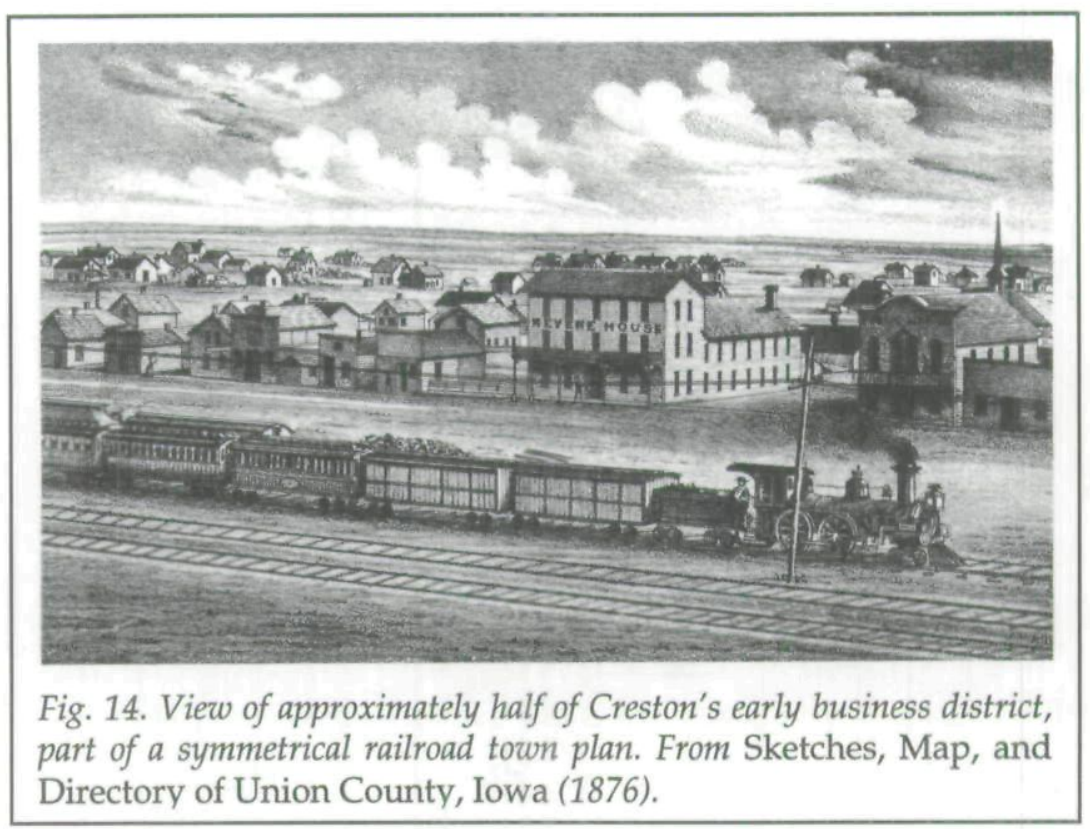

symmetrical railroad plans, tracks and right-of-way were parallel with and within a linear business district (see fig. 12). Among Iowa's county seats, only Creston, platted on the Burlington and Missouri River Railroad in southwestern Iowa, has a symmetrical plan (fig. 14). Officials of the railroad construction company formed a town company and purchased land for the townsite from two early settlers. The railroad's decision to locate its division station, roundhouse, and machine shops at Creston not only ensured rapid growth of the town according to its design, but it also caused the subsequent removal of the county seat from Afton, a Shelbyville square town located nearer the center of the county. ${ }^{40}$

As it had in linear towns, the ideology of the central courthouse square also influenced the evolution of the business districts of the T-towns of Cresco, Emmetsburg, and Allison in northern Iowa. Three landowners platted Cresco on the McGregor and Western Railroad in June 1866 (fig. 15). The northern part of the original plat, surveyed by one of the land-

40. George A. Ide, History of Union County, Iowa (Chicago, 1908). 


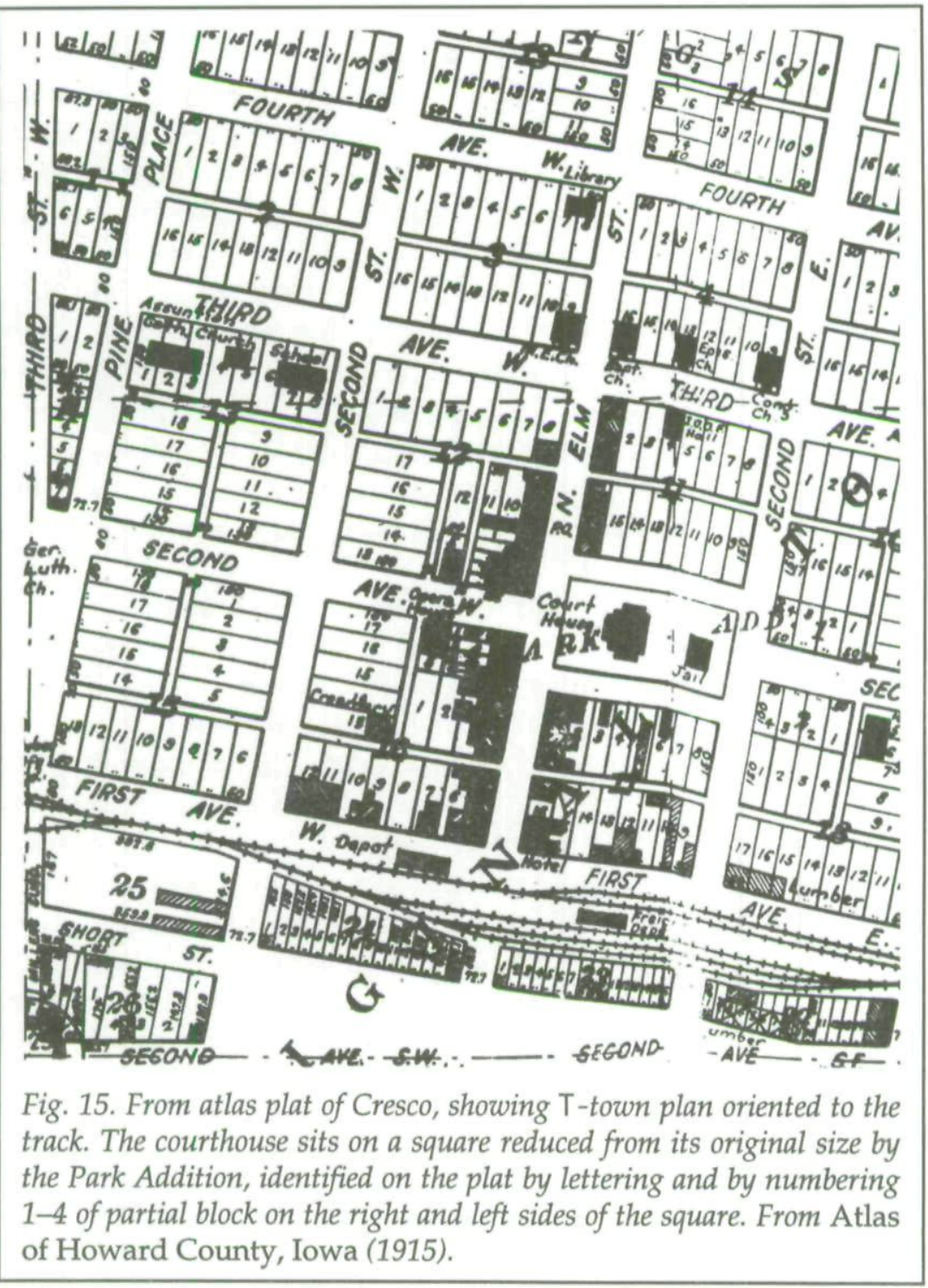

owners, shows blocks conforming to the orientation of the tracks in the spirit of a standardized T-town design. A massive square, identified as "Public Park" on the original plat, blocked the path of a linear business district extending from the tracks, indicating that proprietors did not want their town 
to develop as a T-town, nor did they envision their town becoming a county seat, since it was in the far east central part of the county. As events unfolded, it became both. Within a year of its platting, the original town, the so-called Park Addition to Cresco, compressed the square by enclosing its ends. Taking advantage of a couple of legislative quirks, the town acquired the county seat in the late 1870 s.

The similarities of the plat of Emmetsburg in Palo Alto County with that of Cresco suggest the possibility of complicity in town design, perhaps through railroad officials of the McGregor and Western. It appears more likely, though, that the origins of the towns' forms were unrelated. Like Cresco, the original plat of Emmetsburg has a large square two blocks north of the tracks. Blocks and lots are oriented to the cardinal directions, however, and the greater widths of Broadway and Grand Streets, as well as lot orientation, argue for the presence of the business district on either of those broad thoroughfares. The business district developed along Broadway and, later, in business lots along Main Street in a crossed T-town pattern.

The most fertile ground for railroad town formation in Iowa was in the northwestern quadrant of the state, a region only partially settled when railroads entered it in the 1870s. John Insley Blair was the most influential railroad promoter in that part of the state. Born in New Jersey of Scots-Irish ancestry, Blair had been a grocery-store owner, miller, postmaster, and banker before becoming a financier of businessmen in Scranton, Pennsylvania, who were engaged in the coal and iron industry. In association with those industries, Blair became a director and largest stockholder of the Delaware, Lackawanna and Western Railway. Later, he realized the potential for railroad development in unsettled regions in the West. He first came to Iowa in May 1860 in conjunction with the national convention of the new Republican Party. As a delegate-at-large Blair was invited to tour the state after the convention. During that tour he became acquainted with the opportunities for railroad land grants enacted by the Iowa legislature in $1856 .{ }^{4}$

41. Mary Culbertson Ludwig, "Namer of Towns," Palimpsest 29 (1948), 161-65; B. L. Wick, "John I. Blair and His Associates in Railway Building in Iowa," Annals of Iowa 11 (1914), 489-90. 
Blair eventually owned about one-sixth of the stock of sixteen companies operating in Iowa and Nebraska, and his railroad companies constructed more than eight hundred miles of track in the state. ${ }^{42}$ The various railroads acquired and financed by Blair were popularly known as "Blair Roads." They included the Cedar Rapids and Missouri River Railroad, constructed from Cedar Rapids to Council Bluffs; the Iowa Falls and Sioux City Railroad, which ran between those two cities; and the Sioux City and Pacific Railroad, whose construction northward from the Cedar Rapids and Missouri River line at Missouri Valley, Iowa, linked Council Bluffs to Sioux City.

Blair platted many towns along those lines, including the county seats of Carroll and Boone on the Cedar Rapids and Missouri River line, and Storm Lake and LeMars on the Iowa Falls and Sioux City line. Boone emerged within two miles of Boonesboro, a Shelbyville square town platted by the Boone County judge in 1851 as the original county seat. Before reaching Boone County in the summer of 1865, the Cedar Rapids and Missouri River Railroad Company had persuaded Congress to allow the company to change its original proposed route to the Missouri River, as designated by its land grant, to one that was "better and more expeditious." According to one historian, "the real object was to make the location of the line uncertain in order to extort money, land and privileges from the counties and towns through which the road was to pass." To build to Boonesboro, the railroad induced the county to donate its swampland funds and unsold swampland plus twenty acres of additional land for railroad grounds. The county also agreed to pay the railroad ten thousand dollars in cash and notes. Because the notes could not be guaranteed by "responsible parties" within the three-day limit imposed by Blair, however, he and his associates established the depot and a new townsite on land purchased about a mile east of Boonesboro. In reality, the issue of the railroad's location was probably decided by the ease of construction down Honey Creek and across the Des Moines River south of the two townsites. Of course, an additional incentive for platting a new townsite was

42. Ludwig, "Namer of Towns," 166. 
the profits that would accrue from residential and commercial lot sales, which, considering the nine additions to Boone, all platted by Blair, must have been quite substantial. Boonesboro retained the site of the county seat but not its status as a separate town; it was incorporated into Boone in $1887 . .^{3}$

Plats of Blair's towns varied, but most, like Boone, developed as T-towns. Perhaps the most distinguishing aspect of Blair's county seat towns is that they do not incorporate the courthouse square into the linear business district, although in Carroll and Storm Lake the courthouse is centered on a square only one block east of linear business districts. Even the standardized plan of Sibley, platted by the Sioux City and St. Paul Railroad as the county seat of Osceola County, shows a central square surrounded by business lots. Although the central square became part of a T-town business district along Ninth Street, and the courthouse was located on another square three blocks to the north, the overall design respects the idea of public space at the town core. The plan of Windom, Minnesota, also platted by the Sioux City and St. Paul, is nearly identical to Sibley's plan. Ironically, though, Windom developed as a central courthouse-square town, an aberration in a state with only two of those town forms, and one in which railroad towns dominate in western parts of the state.

THE FORMS OF IOWA'S COUNTY SEATS have significant regional patterns. The core area of central courthouse squares is in south central Iowa, whose settlers came primarily from the Midland culture region. The lineage of those county seats did not pass directly from those immigrants, however. Rather, it came from their form of local government. County commissioners platted nearly all of those county seats but few with linear plans anywhere in Iowa. Commissioners chose a town form that best symbolized the importance of county government. Central courthouse square plans were popular among individuals, too, particularly in the immediate postcommissioner period of the early 1850 s.

43. Republican Atlas of Boone County, Iowa (Knoxville, IA, 1902), 16; Alonzo J. Barkley, "How Boonesboro Lost a Railroad Station," Annals of Iowa 12 (1921), 542. 
The core area of county seats with linear town plans is in northeastern Iowa, but the plan dominated everywhere north of the Midland culture zone. Several linear towns in central Iowa have central squares within or on the perimeter of their principal business districts. Plans of these county seats symbolized conflicting economic and political ideologies in the minds of individual planners. In the Yankee country of northern Iowa, about three of every four county seats had linear plans.

County seats with railroad town plans are most numerous in northwestern Iowa. Some of those towns were platted in unsettled or partially settled counties where the county seat location had not been firmly established. In some counties, the economic importance of the railroad was too overpowering to maintain the county seat at its original site. The pattern of Iowa's counties whose county seats have railroad town forms signifies the beginning of the dominance of railroads in states to the west and north of Iowa. Although the central courthouse square plan had reached a pinnacle in Iowa, its spirit was aging in the national culture. A cluster of central courthouse squares in southeastern Nebraska was to be its last hurrah. 
Copyright of Annals of Iowa is the property of State of Iowa, by \& through the State Historical Society of Iowa and its content may not be copied or emailed to multiple sites or posted to a listserv without the copyright holder's express written permission. However, users may print, download, or email articles for individual use. 